\title{
EVOLUTION IN WAQF JURISPRUDENCE AND ISLAMIC FINANCIAL INNOVATION
}

\author{
Mohammad Abdullah ${ }^{1}$
}

\begin{abstract}
This paper aims to analyse the evolutionary process in the jurisprudential structure of modern waqf (Islamic endowment) and underlines the scope of Islamic financial innovation through the mechanism of waqf. The paper proposes the innovative models of parallel waqf, waqf-based social and financial instruments, waqf-based șukūk, microtakâful, and waqf-based commodity bank. The research adopts the qualitative approach and employs socio-legal research methodology for the analysis. The paper relies on desk-based research. Compared to the classical structure of waqf which was confined within the domain of a perpetual charitable institution, this paper finds that modern waqf has ushered in several new dimensions into its fold. Modern waqf is in the process of re-evolution. Waqf, in the current scenario, has evolved into a financial product, a property-conveyance tool, an instrument of contract, an investment tool, a risk mitigation mechanism and an incorporated entity. The scope of this paper is limited to analyzing the jurisprudential evolution of waqf and its impact on the Islamic finance industry. It does not seek to discuss the overall role or impact of waqf on the society as a whole. This paper also does not endeavor to compare and contrast the mechanism and modalities of other philanthropic institutions vis-ā-vis waqf. This paper examines the jurisprudential underpinnings of waqf and their implications and applicability to the Islamic finance industry. The paper draws on the process of how the mechanism of waqf has already been employed to develop various innovative Islamic financial products and how this process can be a catalyst for further innovation in the Islamic finance industry. The main contribution of the paper is encapsulated in the analysis of how the jurisprudential structure of the modern waqf has been evolving in the last few decades to accommodate the modern needs of Islamic finance. It further enumerates a few innovative Islamic financial products which can be developed by exploiting the available flexibility in the evolved version of modern waqf.
\end{abstract}

Keywords: Waqf, Charity, Charitable Trust, Endowment, Innovation, Islamic Finance, Social Finance

JEL Classification: O20, O31, P13

Received : July 16, 2017

Revised : July 19, 2018

Accepted : August 06, 2018

1. FAB, Siraj (Islamic Window of First Abu Dhabi Bank), nadwi.ab@gmail.com 


\section{INTRODUCTION}

In its technical setting, the conceptual framework of waqf (Islamic endowment) is easily adaptable. The inherent flexibility of the waqf mechanism provides enough scope for the institution to be structured in multifarious ways. It is critically important that the flexible nature of waqf be adequately exploited to maximize the benefits to the community in line with modern needs and circumstances. From its jurisprudential perspective, waqf has an in-built capacity to transcend the limitations of other charitable institutions. Waqf can ably accommodate the legal and transactional intricacies of various non-profit institutions as well. In the current scenario, the institution of waqf has attained special relevance with reference to the newly emerged industry of Islamic finance.

The emergence of the Islamic finance industry has been instrumental in streamlining the institution of modern awqā $f$ (pl. of waqf). Waqf and Islamic finance have a shared background in terms of their embedded Shari 'ah (Islamiclaw) principles and ethical foundations. In other words, the conceptual premises of Islamic finance corroborate the ideological underpinnings of waqf. In the context of Islamic finance, the role of waqf can be crucial both as a vehicle of property conveyance and as an instrument of contract (MIFC, 2014; Khaleel and Abdullah, 2016).

In the Islamic finance industry, the mechanism of waqf has already been employed to develop various innovative financial products. The list of waqf-based products includes takāful (Islamic insurance), micro-takāful, Islamic microfinance, Islamic microcredit, qard hasan (benevolent loan) and Islamic unit trust (MIFC, 2014). In addition, the mechanism of waqf exhibits a far greater scope for the development of benevolence-oriented products such as kafälah (provision of security), damānah (provision of guarantee), amānah (safekeeping) and 'äriyah (loan of an item for temporary usage).

This paper aims at analyzing the process by which modern waqf has evolved, followed by a critical examination of how the evolved version of waqf can be used for Islamic financial innovation. Finally, this paper proposes innovative models of parallel waqf, waqf-based șukūk, a waqf-based commodity bank and micro-takâful based on the hybrid model of waqf-wakālah-kafälah.

\section{LITERATURE REVIEW}

\subsection{Waqf and Islamic Finance}

The phenomenon of Islamic finance has played a role in streamlining the institution of modern awqāf, and vice versa. Islamic finance and waqf share fundamental norms, values and ethical considerations, including the objectives of promoting equity, social justice and financial inclusion (ISFR, 2014). They differ in that Islamic finance is oriented to making profits while waqf is not for profit; however, theoretically both institutions endeavour to achieve similar ends (Çizakça, 1998, 2011).

Beside the possibilities offered by innovative waqf-based financial devices, the mammoth size of cumulative global awqāf presents a huge opportunity for Islamic finance, both on the assets and liability sides of the balance sheet (Budiman, 2011). Waqf can be rightly described as "the sleeping giant of Islamic finance" (Tamanni Views, 2013: 1). Islamic finance has substantial opportunities to invest 
in unproductive waqf properties on a profit-and-loss-sharing (PLS) basis. Islamic finance can deploy its funds only in Sharī 'ah-compliant avenues; and on this front, waqf provides an ideal opportunity for Sharīah-compliant investments (MIFC, 2014). In this sense, awqāf can offer massive scope for Islamic finance in asset and liquidity management.

In general, awqāf need the services of Islamic financial institutions (IFIs) to secure short- and long-term financing as well as for asset management. For its part, Islamic finance may need awqāf for investment purposes. Table 1 elucidates the possible synergies between waqf and IFIs. It contains a list of potential avenues for collaboration between waqf and Islamic finance to further the cause of both industries.

Table 1.

Synergies Between Waqf and Islamic Financial Institutions

\begin{tabular}{|c|c|}
\hline Waqf & Islamic Financial Institutions (IFIs) \\
\hline Need for efficient asset management & IFIs can provide Sharî'ah-compliant asset management services. \\
\hline Need for financial investment & $\begin{array}{l}\text { IFIs can provide services to awqāf on the asset and liability sides } \\
\text { of the balance sheet. }\end{array}$ \\
\hline Need for financial products & $\begin{array}{l}\text { IFIs can facilitate the issuance of Îukūk, equity (waqf share) and } \\
\text { qarI Ílasan. }\end{array}$ \\
\hline Need for banking products & $\begin{array}{l}\text { IFIs can provide safekeeping (wadī'ah) and mulārabah accounts } \\
\text { for awqāf deposit and investment purposes. }\end{array}$ \\
\hline $\begin{array}{l}\text { Intermediation between wāqif } \\
\text { (endower) and waqf }\end{array}$ & IFIs can facilitate fund collection on behalf of awqāf (deposit). \\
\hline Need for takāful for waqf properties & IFIs can provide takāful services to awqāf. \\
\hline
\end{tabular}

Waqf incorporates a wide array of possibilities for all its key elements; i.e. wāqif (endower), mutawallī (trustee), beneficiaries and objectives. For instance, a waqf can be created by an individual, a group of individuals, a corporation, a nonprofit institution, as well as a governmental body. Similarly, the modes of waqf

Table 2.

Possible Structures in Waqf

\begin{tabular}{|c|c|c|c|c|}
\hline Modes of Waqf & $\begin{array}{c}\text { Wāqif } \\
\text { (Endower) }\end{array}$ & $\begin{array}{c}\text { Mutawallī } \\
\text { (Trustee) }\end{array}$ & Beneficiary & Objectives \\
\hline Real estate & Individuals & Individuals & Individuals & $\begin{array}{l}\text { Religious/Charitable/ } \\
\text { Private }\end{array}$ \\
\hline Cash & Group & Group & Group & $\begin{array}{l}\text { Religious/Charitable/ } \\
\text { Private }\end{array}$ \\
\hline Stocks & Corporation & Corporation & Corporation & $\begin{array}{l}\text { Religious/Charitable/ } \\
\text { Community }\end{array}$ \\
\hline Îukūk & Institutions & Institutions & Institutions & $\begin{array}{l}\text { Religious/Charitable/ } \\
\text { Private }\end{array}$ \\
\hline $\begin{array}{l}\text { Any Sharī'ah- } \\
\text { compliant } \\
\text { non-consumable } \\
\text { property }\end{array}$ & $\begin{array}{l}\text { Government } \\
\text { bodies }\end{array}$ & $\begin{array}{l}\text { Government } \\
\text { bodies }\end{array}$ & $\begin{array}{l}\text { Government } \\
\text { bodies }\end{array}$ & $\begin{array}{l}\text { Religious/Charitable/ } \\
\text { Welfare/Community }\end{array}$ \\
\hline
\end{tabular}


may include real estate (including commercial, non-commercial and residential buildings), agricultural lands, cash, stocks, Îukūk, waqf-share (certificate) and any other Sharī'ah-compliant non-perishable property/valuable. Also, the role of the mutawalli can be executed by any entity that is fit and qualified for making a waqf. Similarly, there is a wide scope for the potential beneficiaries of a waqf. Table 2 explains this further.

Table 3 contains the list of possible modes of waqf which are applicable in the contemporary time. Additionally, it provides an overview of the distinctive qualities and management features of different modes of waqf.

Table 3.

Trends in Modes and Management of Waqf

\begin{tabular}{|c|c|c|}
\hline Modes of waqf & Management & Features \\
\hline Real estate & $\begin{array}{l}\text { Traditional mode of waqf, } \\
\text { Individually appointed mutawallī, } \\
\text { institutional mutawallì (new } \\
\text { trend) }\end{array}$ & $\begin{array}{l}\text { Illiquid, immovable, permanent, } \\
\text { ideal for infrastructure and } \\
\text { housing }\end{array}$ \\
\hline Cash & $\begin{array}{l}\text { A combination of traditional and } \\
\text { contemporary mechanisms of } \\
\text { waqf. } \\
\text { Mostly managed by international } \\
\text { charities }\end{array}$ & $\begin{array}{l}\text { Liquid, movable, perpetual and } \\
\text { temporary, investible, economies } \\
\text { of scale }\end{array}$ \\
\hline Modes of waqf & Management & Features \\
\hline Stock & $\begin{array}{l}\text { New model, mostly managed } \\
\text { by corporate and institutional } \\
\text { mutawalli }\end{array}$ & $\begin{array}{l}\text { Liquid, perpetual cash flow, risk } \\
\text { of fluctuation in the value of the } \\
\text { capital as well as in cash flow }\end{array}$ \\
\hline Îukūk & $\begin{array}{l}\text { New mechanism of perpetual } \\
\text { donation. Generally, managed } \\
\text { by corporate and institutional } \\
\text { mutawallī }\end{array}$ & $\begin{array}{l}\text { Tradable, relatively less liquid, } \\
\text { less fluctuation, continuous cash } \\
\text { flow }\end{array}$ \\
\hline Waqf-share & $\begin{array}{l}\text { New model of perpetual charity, } \\
\text { mostly managed by charities }\end{array}$ & $\begin{array}{l}\text { Project-oriented, subscription- } \\
\text { based donation, investible lump } \\
\text { sum }\end{array}$ \\
\hline Intellectual property & $\begin{array}{l}\text { Innovative model, specific to } \\
\text { contemporary world, managed by } \\
\text { both individuals and institutions }\end{array}$ & $\begin{array}{l}\text { Intangible asset, continuous } \\
\text { revenue generating, non-tradable }\end{array}$ \\
\hline
\end{tabular}

Source: Author

Waqf of real estate constitutes a traditional model in which the endowed land or building is either placed for commercial lease and the related rentals are deployed for charitable purposes, or the given property, being residential, accommodates the waqf beneficiaries. The model of cash waqf, on the other hand, is a common phenomenon with national and international Muslim charities. They raise cash waqf funds and invest them in Sharī'ah-compliant avenues that generate proceeds which in turn are employed for serving charitable causes.

Similarly, the mechanism of waqf-share is utilised to provide the potential endowers with the opportunity to participate in a waqf pool by subscribing to an intended number of fixed-priced waqf shares; i.e. donation certificates, 
by contributing the given amount of money. The waqf of stocks, Îkūk and intellectual property are relatively modern phenomena where the endower can pledge the proceeds of his/her financial assets such as stocks of listed companies or Îkūk as waqf. In addition, waqf of intellectual property such as an author's pledge of accruing royalty for charitable causes can be a reality in the domain of modern waqf.

\section{RESULT AND FINDING}

\subsection{Waqf: The Evolutionary Process}

In their initial stages, the institution of waqf and Sharī'ah evolved together (Hennigan, 2004). Putting its spiritual merits aside, the increased relevance of waqf in its early phase of history may be ascribable to the restrictive regulations attached to the institutions of zakāh and mawārith (rules of inheritance), which are highly regulated Sharī' ah institutions. For instance, the main beneficiaries of zakāh are specifically defined in Sharī'ah (al-Qardawi, 1985). Similarly, for mawārith, the categories of the heirs and their respective shares are strictly determined. In this context, the flexible mechanism of waqf provided a middle way for both institutions. A deed of waqf can be structured to benefit whomsoever the waiqif wishes, including the members of his own family, friends, as well as the rich and the poor (Kahf, 1999). Similarly, through the mechanism of waqf a person can provide for his heirs and others according to their respective needs and not in a restrictively fixed proportion. Waqf in this capacity played a crucial role in providing a relaxed alternative to the narrowly regulated Islamic legal institutions such as zakāh, wașiyyah (Islamic will) and mawārith (Çizakça, 1998).

The mechanism of waqf, perhaps due to its flexibility, was popular among the companions of the Prophet (peace be upon him). To this end, there are instances where the Companions employed the innovative mechanism of waqf to respond to unforeseeable contingencies (al-Khassaf, 1904). Waqf was used in early Muslim societies as a multi-purpose adaptable tool which served the purpose of indemnifying the named beneficiaries against their vulnerability to a future unfavorable event. This proposition is supported by the clauses of some Companions' waqf deeds. For example, Zubayr ibn 'Awwām and Sa 'd ibn Abī Waqqās made waqf of their houses with the stipulations that their progeny, especially their daughters, would be entitled to reside in them in the event they had no shelter due to either poverty or divorce or widowhood (al-Khassaf, 1904: 17). Similarly, ' $\bar{A}$ 'ishah and 'Uqbah ibn 'Āmir endowed their properties with the condition that the residue would return to their most deserving relatives (alKhassaf, 1904: 18). These instances demonstrate how the flexibility of waqf was effectively utilised by the early generations of Muslims to condition its usage for multifarious objectives.

The concept of waqf is based on the premises of tabarru 'at (voluntary benevolent disposition). Though there are other devices of tabarru' $\bar{a} t$ as well including the ordinary șadaqāt (plural of șadaqah, charity), hadiyah (gift) and qard hasan (benevolent loan), these devices are not as flexible as waqf. Technically, the point of divergence between waqf and other tabarru' 'at is characterised by the treatment of their respective ownerships (Zuhayli, 1996; Abu Zahra, 1972). In other forms 
of tabarru 'ät, apart from waqf, the ownership of the given subject matter transfers from the donor to the beneficiary. In waqf, the ownership of the subject matter becomes suspended (Kahf, 1999). Due to this underlying divergence between waqf and other tabarru' $\bar{a}$ t, there is relatively more scope for innovation and ingenuity through waqf than the other variants of charitable giving.

The legal requirements of waqf distinguish it from an absolute șadaqah in many aspects. These distinctions can be summarised in the following five points:

(1) The subject matter of waqf cannot be owned in absolute terms, while the subject matter of sadaqah is fully owned by the beneficiary.

(2) The stipulations of the wāqif must be adhered to. In contrast, the stipulations of the donor of sadaqah do not enjoy this status. Instead, any such stipulations would be taken merely as mashwarah ${ }^{2}$ (suggestion) and not as mandatory condition (al-Shaybani, 1997: 250).

(3) If the wäqif becomes an apostate, his waqf would become void whereas the apostasy of the donor of sadaqah would not affect the legal status of sadaqah in any way (Ibn 'Ābidīn, 2010).

(4) The subject matter of a waqf could never be employed by the mutawalli for Sharī'ah non-compliant purposes; however, a șadaqah could possibly be used by its new owner in any manner.

(5) Waqf constitutes the property of the whole community, while sadaqah belongs to a particular individual.

In terms of its objectives, the device of waqf covers several possibilities. It may be employed for religious, philanthropic, public, private and other charitable purposes. The possible subject matter of waqf may include a property which either generates usufruct/fruits or revenues. For instance, as shown in Figure 1, a wāqif may choose to endow a usufruct-bearing subject matter such as a well/ canal that provides drinking/irrigation water to the intended beneficiaries; or an orchard/agricultural land which bears fruits/grains to be directed towards serving charitable purposes. Similarly, Figure 1 shows that there is an equal possibility of endowing a revenue-generating subject matter as waqf, such as a commercial building which is to be leased, or a cash waqf which is to be invested to generate proceeds.

The classical awqāf mostly constituted immovable properties. The most significant diversion from this mode of donation came when waqf of movable properties such as cash, jewellery, seeds and agricultural equipment was permitted by the early Hanafī jurist Imām Zufar (Ahmad, 2015). The relaxation of the jurisprudential prohibition of waqf of movable properties paved the way for further evolution of waqf. The possibility of employing waqf as a financial product

2. Al-Shaybānī argues that "if a donor gives away his house to someone with the stipulation that the latter would reside in it, the stipulation of the donor would be taken as a suggestion only. Similarly, the stipulations of a mūsī too would be considered as mashwarah" (1997, p. 250). This raises the question of the basis for the necessary requirement of its adherence to waqf. If the hadīth "al-muslimūn 'alā shurütihim" (Muslims are bound by the conditions they make) provides the basis for waqf-related axioms, why is the same not applied to other institutions as well? The answer lies, perhaps, in the nature of ownership of a waqf. 


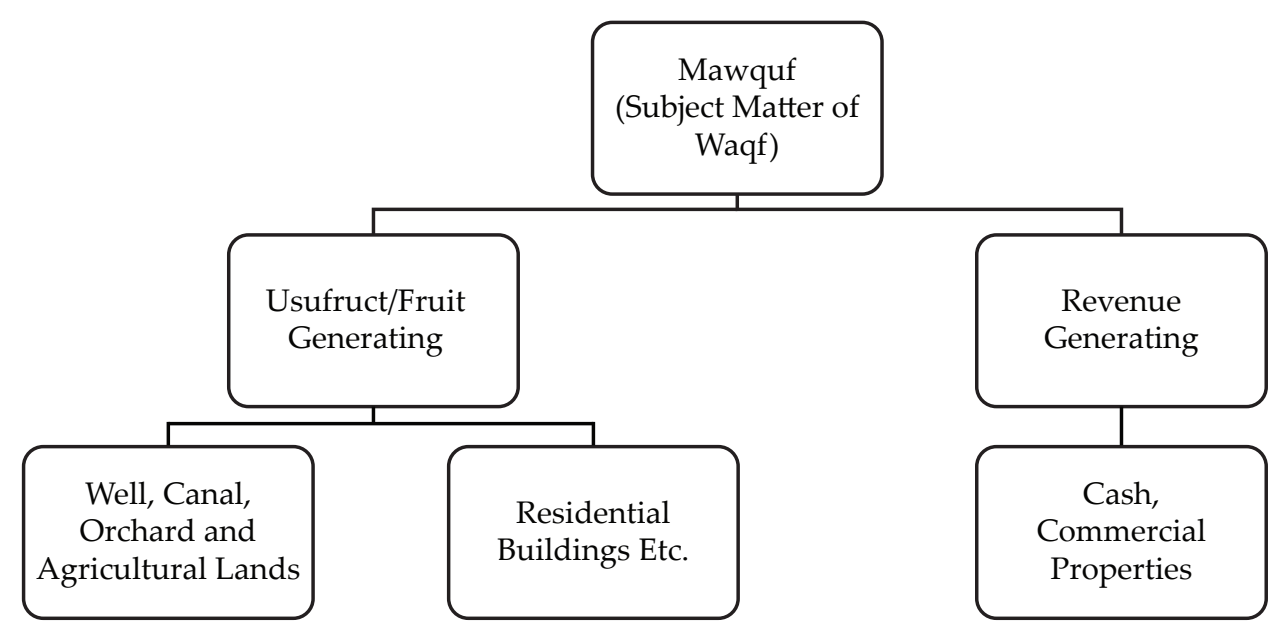

Figure 1.

Subject Matter of Waqf

is ascribable to this jurisprudential position of Imam Zufar, which was supported by some Mālikī jurists as well (Ahmad, 2015).

With reference to early Islamic financial services, it is argued that it was through the pools of cash waqf that such services were provided for the community (Çizakça, 1998). The most vivid examples of such waqf pools can be traced back to the $16^{\text {th }}$ and $17^{\text {th }}$ century. For example, during the Ottoman era, Muslim communities widely practised waqf-based financial services. The waqf pools comprising numerous cash waqf donations from different individuals were employed through the mechanism of $i_{\text {stighla }}^{3}$ to finance various clients (Çizakça, 2000: 47-48). Additionally, waqf pools were vital in providing the seed capital to small and medium enterprises (SMEs) on mudārabah basis as well as for providing funds for consumption purposes (Çizakça, 1998). Notwithstanding this development, for a long period of its history, the Sharī'ah permissibility of cash waqf remained fiercely disputed (Islahi, 2013; Çizakça, 2000; Mandaville, 1979). The permissibility of cash waqf gradually received acceptability outside Ottoman Turkey but not in a global sense. Jurists in countries such as Egypt, Iran and the Indian sub-continent remained reluctant to approve the permissibility of cash waqf till as late as the beginning of the $20^{\text {th }}$ century (Çizakça, 2013). The progress of evolution in waqf continued, and by the early $20^{\text {th }}$ century, precisely in 1907, waqf of "company shares as well as European perpetual bonds" was permitted by some leading scholars (Çizakça,

3. Istighlāl was, apparently, a fictitious sale contract wherein "the borrower handed over to the lender a piece of real estate, supposedly as a sale, but actually in a pawn. If the borrower redeemed his debt after a year, the asset reverted to him. In the meantime, the lender leased the asset to the borrower (so that the borrower could go on using it)" and would pay the rent (Çizakça, 2000: 46). 
2013: 7-8). The history of waqf-based associated companies can be traced back to 1967 in Turkey (Çizakça, 2013).

In terms of its global acceptability, the resolution of the International Islamic Fiqh Academy (IIFA), Jeddah, on the Sharī'ah permissibility of cash waqf has confirmed that the modern waqf has come of age by evolving into a financial product (IIFA, 2013; 15/6, 140). Notably, the permissibility and possibility of cash waqf has significantly widened the scope of further evolution of modern awqāf (Mohsin, 2013). In the modern context, cash waqf potentially can be employed for a plethora of schemes (Mohsin, 2014; 2009). The concept and mechanism of cash waqf has ignited a great amount of interest from the various stakeholders of waqf institutions including the Islamic finance industry. The nature, technicalities and nuances of banking and financial products are more compatible with the cash version of waqf than with its other illiquid variants.

Awqā in the contemporary scenario have received many innovative reformations. For instance, the domain of figh has been extended to accommodate some new trends and developments in the waqf industry. Compared to the traditional awqāf, which mainly constituted real estate, new aw $q \bar{a} f$ comprise waqf of cash, stocks, securities, intellectual property rights and other liquid and illiquid financial instruments by individual, institutional and corporate wāqifs (Suhaimi, Rahman and Marican, 2014; Hamad, 2015). Though the jurisprudential debate over the Sharī' ah basis of corporate waqf ${ }^{4}$ is still going on among modern jurists, the practice of corporate waqf is not new. For instance, the first noted corporate waqf was created by Koc Holdings in Turkey as early as 1967 (Çizakça, 2011b). The Turkish corporation declared a waqf of its 10,000 shares and appointed its own subsidiary Koc Foundation as the mutawalli of the waqf (Çizakça, 2011b).

In the contemporary waqf literature, the concept of corporate waqf received new interest with the creation of waqf by a Malaysian corporation, Johor Corporation (JCorp), which dedicated its shares worth RM 200 million as waqf in 2006 (Ramli and Jalil, 2013). Interestingly, the initiative of JCorp is not limited only to the creation of waqf by a corporate body but also involves the administration of the given waqf by another corporate body, namely WANCORP, a subsidiary of JCorp (Mohsin, 2009)

From the fighi (jurisprudential) perspective, the case of corporate waqf seems exceptionally interesting given the fact that in this case the practice evolved prior to the proper conceptualisation of its legal basis in Shari' ${ }^{-}$ah. While the modern Sharī'ah jurists are yet to reach a consensus on whether a legal entity can be a wāqif or not - which is the case with corporate waqf - the practice of corporate waqf is on the rise. In the recent development on the issue, while "recent Turkish law of waqfs clearly grant legal personality to waqfs" (Çizakça, 2013: 9), a new framework of waqf law has been jointly prepared by the Islamic Development Bank/Islamic Research and Training Institute (IDB/IRTI) and the Kuwait Public Foundation (KPF) which

4. The concept of corporate waqf is still a little blurred, as the term has not been precisely defined in the available literature on waqf. In the contemporary waqf literature, the term corporate waqf possibly refers to two phenomena, namely, a waqf by a corporate body in the form of its shares and a waqf managed by a corporate body as the mutawalli (trustee) of waqf. 
proposes the Sharī' ah permissibility of incorporating awqāf. According to the draft waqf law of IDB/IRTI and KPF, the incorporated waqfs are defined as "waqfs that enjoy full corporate status. Thus they can sue and be sued. They also provide full owner and entity shielding to their trustees" (Çizakça, 2013, p. 5).

Not only these, what signifies a new trend of evolution in the modern figh of waqf is that the Sharī' ah acceptability of temporary waqf, which was once advocated by "the new IDB/IRTI and KPF draft law" (Çizakça, 2013: 12), has already been accepted. The new standard on waqf issued by the Accounting and Auditing Organization for Islamic Financial Institutions (AAOIFI) holds "In principle Waqf should be eternal. Nevertheless, temporary Waqf is also permissible when the donor desires to get back his property after a specific period" (AAOIFI 33/3/1/4). The proponents of temporary waqf ascribe its permission to be based on the analogy of a voluntary benevolence, the benefit of which recurs. For instance, according to Kahf (1999) the jurisprudential scope for voluntary charity is extensively open in Shari'ah, and thus there seems no valid reason why a waqf shall be necessarily perpetual. In this regard, the closest proximate for the analogy of temporary waqf can be found in the Sharī'ah-prescribed benevolent loan (qard hasan) with the only difference that while the latter entails the transfer of ownership of the subject matter with the condition of its equal return after a while, the former warrants the suspension of the ownership for a defined period of time (Abdullah, 2015). Thus, apparently, the concept of temporary waqf (waqf mu'aqqat) is not in conflict with jurisprudential rulings on waqf (Kahf, 1999; Manjoo, 2012). Thus, the mechanism of time-bound waqf is well-poised to sharpen the scope and prospects of innovation in Islamic finance through waqf.

Modern waqf is gradually evolving into a multidimensional institution. Due to the incorporation of several new features into its structures and mechanisms, modern waqf implies as much a financial product as a charitable institution. Figure 2 exhibits, from bottom to top, the evolutionary process of waqf from a mechanism of benevolence to representing a corporate entity. As shown in the diagram, though contemporary waqf has turned into an institution of multifarious usage, in general, it is more inclined towards covering the features of a financial institution. This phenomenon creates a new pitch of collaboration between waqf and Islamic finance.

The evolution of waqf into a corporate entity as well as into a legal personality has further widened the scope of innovation for the institution (Çizakça, 2013; Mohsin, 2014; Hamad, 2015). In a nutshell, in the current scenario, "waqf can create a company and a company can also create waqf" (Abdul-Karim, 2010, p. 19). The implications of this evolutionary progress of waqf are many, particularly in the context of Islamic finance. 


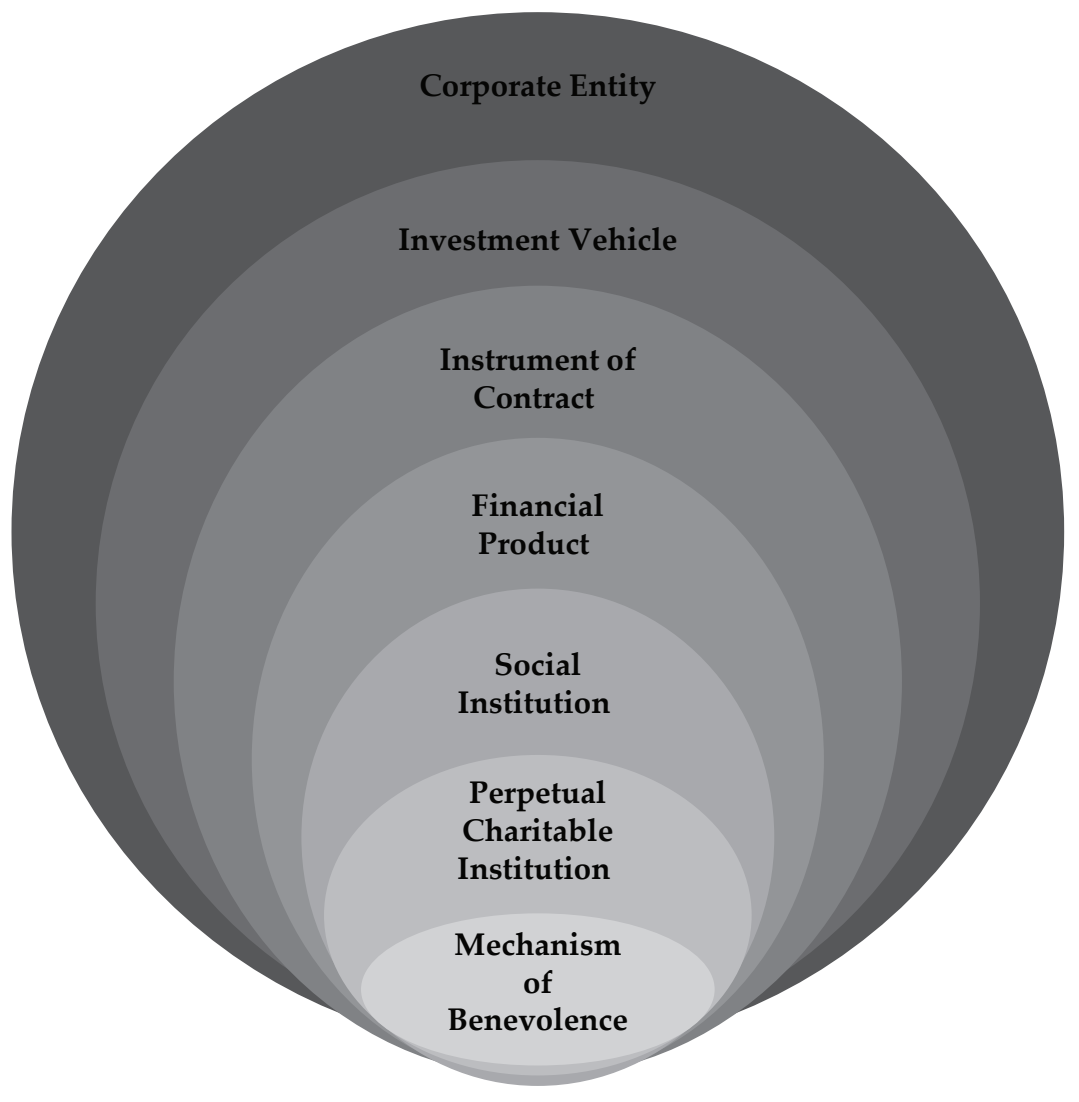

Figure 2.

Evolved Versions of Waqf

\subsection{The Factors of Evolution in Contemporary Waqf}

The speedy pace of evolution in the jurisprudence of waqf as witnessed in the last few decades is largely unprecedented. This phenomenon can be ascribed to several possible factors. One key factor appears to be the closer involvement of national and international bodies of Islamic scholars-such as the IIFA, AAOIFI, and others-in re-analysing the doctrines of waqf in the light of modern needs. This process gathered considerable vitality after the de-colonisation of the Muslim world. This process can be considered a manifestation of globalization, which provided the platform for various stakeholders of waqf from different jurisdictions to collaborate. The major impetus for the modern evolution of waqf jurisprudence is linked with the belief of the community that the jurisprudential basis of waqf needs further exploration for innovative tweaking (Kahf, 2004; Joseph, 2014).

In hindsight, the contemporary approach of 'ulama (Islamic scholars) to expanding the domain of waqf jurisprudence is largely dependent on three fighi principles: 'urf (customary practice), mașlahah (benefit of the community) and 
istiḩsān (juristic preference). A composite of these principles lays the jurisprudential basis for the application of fresh reasoning in the existing waqf jurisprudence which entails accommodation of the emerging trends in modern waqf. The Sharī'ah permissibility of corporate waqf, for example, is vividly based on 'urf. The permissibility of hikr or ijāratayn (long-term waqf lease) and istibdāl (swap) of waqf properties in modern times are deduced from the application of mașlahah (Wizārat al-Awqāf wa al-Shu'ūn al-Islāmiyyah, 2006). In the same vein, the concept of waqf mu'aqqat (temporary waqf) as well as waqf al-nuqūd (cash waqf) can be permissible only in the light of istihsān (Ellias, Kadir and Harun, 2015). Interestingly, the modern evolutionary revisiting of the figh of waqf is greatly characterised by the implicit integration of waqf-related rulings from different schools of jurisprudence. For instance, while the permissibility of waqf al-nuqud (cash waqf) is derived from the opinion of the classical Hanafi jurist Imam Zufar, the basis for the validation of waqf mu'aqqat (temporary waqf) is being sought in the light of the Māliki opinion. Similarly, while the ground for istibdāl of waqf properties lies in the opinion of the Hanbalī School of jurisprudence, the opinion of the Shäfi 'i School is resorted to for arguing the permissibility of endowing movable assets independently as waqf (Kahf, 2004).

In a nutshell, in the early Islamic societies, waqf functioned in a simple but limited structural setting. The identity of waqf in this phase of history remained as a tool of voluntary charity that took almost one-and-a-half centuries to evolve into a full-fledged charitable institution. For the modern waqf, the mechanism of waqfbased microfinance, microcredit, qarI Íasan and others demonstrate examples of waqf's evolution into a financial product.

\subsection{Waqf: An Instrument of Contract}

The institution of waqf, by its very nature, extends an informal or non-contractual form of takâful (Islamic insurance) cover to the vulnerable people residing in its vicinity. Be it a need for emergency relief or a recurring form of financial or socioeconomic suffering of the vulnerable, the existing awqā $f$ of given localities have been traditionally envisaged to extend material and non-material assistance. However, in the current scenario, the evolution of waqf into a device of contract has made it possible to provide waqf-based takāful schemes in a formal and professional manner.

Waqf as an instrument of contract is already being employed in the takâful industry (Rahman and Ahmad, 2011). According to Al-Humoudi (2012: 112), "The only application of takäful which completely complies with Sharī'ah, and receives no objection among the Islamic experts, is the takäful with waqf model". To simplify it, it is worth underlining that the concept of tabarru 'is critically important to resolve the problem of contract in takäful. In other words, a takäful contract that is bilateral between the participant and the operator is deemed Sharīahrepugnant (Wan and Rahman, 2011). The underlying reasoning for the Sharī'ah non-compliance of such a bilateral takäful contract is the involvement of gharar (ambiguity) and maysir (gambling) in it (Bakar, 2009). This technical issue has been meticulously remedied by the employment of the waqf mechanism. Since a waqf is a unilateral donation, its usage for the takâful pool adequately resolves not only 
the contractual problem of takāful but also the problem of surplus distribution (Ali, Odierno and Ismail, 2008).

Similarly, waqf is suggested to be employed as a mechanism of contract for Sharī'ah-compliant pension funds (Manjoo, 2012). As per the proposed model, the mechanism of waqf can be employed for collecting the contributions from the pension applicants or any third party wäqif. The pool of the collected sum is invested and the nominated beneficiary receives the pension benefits from the pool in line with the specifications of the waqf deed (Manjoo, 2012).

\subsection{Waqf: An Investment Vehicle}

The evolution of waqf into an investment vehicle is characterised by the consistently growing interest in revival and renovation of existing awqā f through profit-oriented investment schemes. A huge number of $a w q \bar{a} f$ need financing for the purpose of either revival or renovation. This positions the institution of awqā $f$ as a promising Sharī'ah-compliant investment avenue for Islamic financial institutions. The intensity of modern $a w q \bar{a} f^{\prime} s$ financial needs is unprecedented in the history of the institution. This phenomenon may best explain the evolution of modern waqf into a financial investment vehicle.

On the practical side of it, the typical example of how the modern awqā $f$ has been treated as an investment avenue is embodied by the IDB subsidiary APIF (Awqaf Properties Investment Fund). APIF invites subscription capital from the member countries for investing in dilapidated awqā $f$ on a mudārabah basis, and it distributes the shares of the underlying profit from the given projects among the capital providers (IDB, 2015). Figure 3 explains how APIF treats awqāf as an investment vehicle.

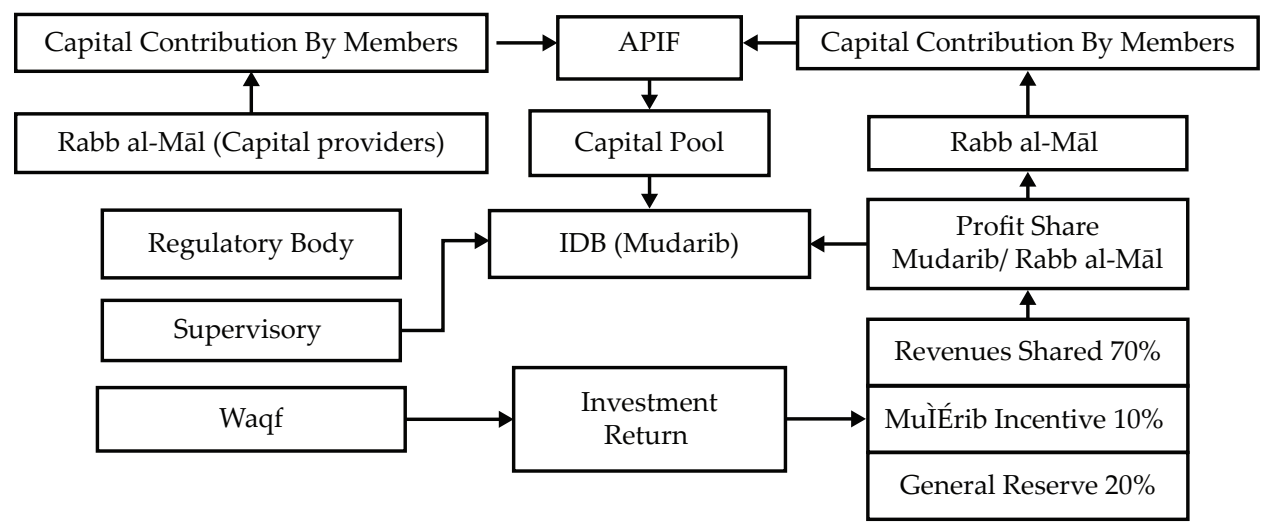

Figure 3.

Awqā $f$ as an Investment Vehicle 
As per Figure 3, APIF identifies the waqf properties which require investment for their development. APIF raises a specific amount of funds by inviting the member institutions to contribute capital as rabb al-māl. APIF appoints the Islamic Development Bank (IDB) as the mudārib and delivers the allocated pool of capital to it for investment in the underlying waqf properties. The proceeds generated through the project are divided into three sections: general reserve, mudārib share, and revenues to be shared among the capital providers (rabb al-māl). Thus, waqf in such scenarios offers a good investment avenue.

\subsection{Waqf: An Instrument of Benevolence}

The institution of waqf is envisaged to play a critical role in poverty alleviation through waqf-based microfinancing schemes (Alpay et al., 2015). A waqf-based microfinance scheme can ideally be helpful in resolving the two primary challenges of the sector: profitability and sustainability. Given the charitable as well as perpetual nature of waqf, both issues can be easily tackled in waqf-based microfinance schemes (Ahmad, 2007; Shirazi, 2014). In other words, since waqf constitutes a non-profit institution, there is a minimal scope for the factor of profitability through waqf-based microfinance schemes. Similarly, since the original nature of waqf invokes perpetuity (although temporary waqf is also permissible), waqf-based capital is better pitched for sustainability.

Similarly, employment of the waqf mechanism can be critically significant for micro-takâful operations. For the purpose of providing micro-takāful cover to the extremely poor, it can be proposed that some wealthy individuals subscribe to the waqf-based schemes in favour of such beneficiaries. For example, if a micro-takāful scheme for the health of poor persons or the crops of small farmers requires the participant to contribute USD 50 a year, the scheme may be subscribed to by a third person (the potential wāqif) in favour of a random or specific beneficiary. A donor could subscribe to the scheme for as many potential beneficiaries as he may wish. For example, to provide the waqf-based micro-takâful service to five beneficiaries, the donor would contribute USD 250. In an alternative scenario, by contributing USD 250 a donor may wish to provide the takaful cover to just one beneficiary for five years. The waqf-based takäful operator, which would underwrite the takâful contract, would hold back any surplus or investment return in the waqf pool. In case a deficit occurs in the waqf pool, the operator may invite an existing or potential wāqif to further contribute to the pool in order to maintain the sustainability of the waqf capital. In this regard, takâful schemes based on a hybrid of waqf, wakālah and kafālah can be structured.

The following terms may be used by the wäqif to favour specific individuals for the hybrid of waqf-wakālah-kafālah for micro-takāful:

- Silat al-rahm takäful scheme (for the provision of micro-takäful to the financially vulnerable blood relatives of the wäqif)

- Birr al-wālidayn takāful scheme (for the economically marginalised friends of the wāaif's parents)

- Husn al-jār takāful scheme (for the needy neighbours of the wāqif)

- Kafälat al-yatìm takāful scheme (for the education and provisions of an orphan). Figure 4 illustrates the functions of such a waqf-based takäful scheme. 


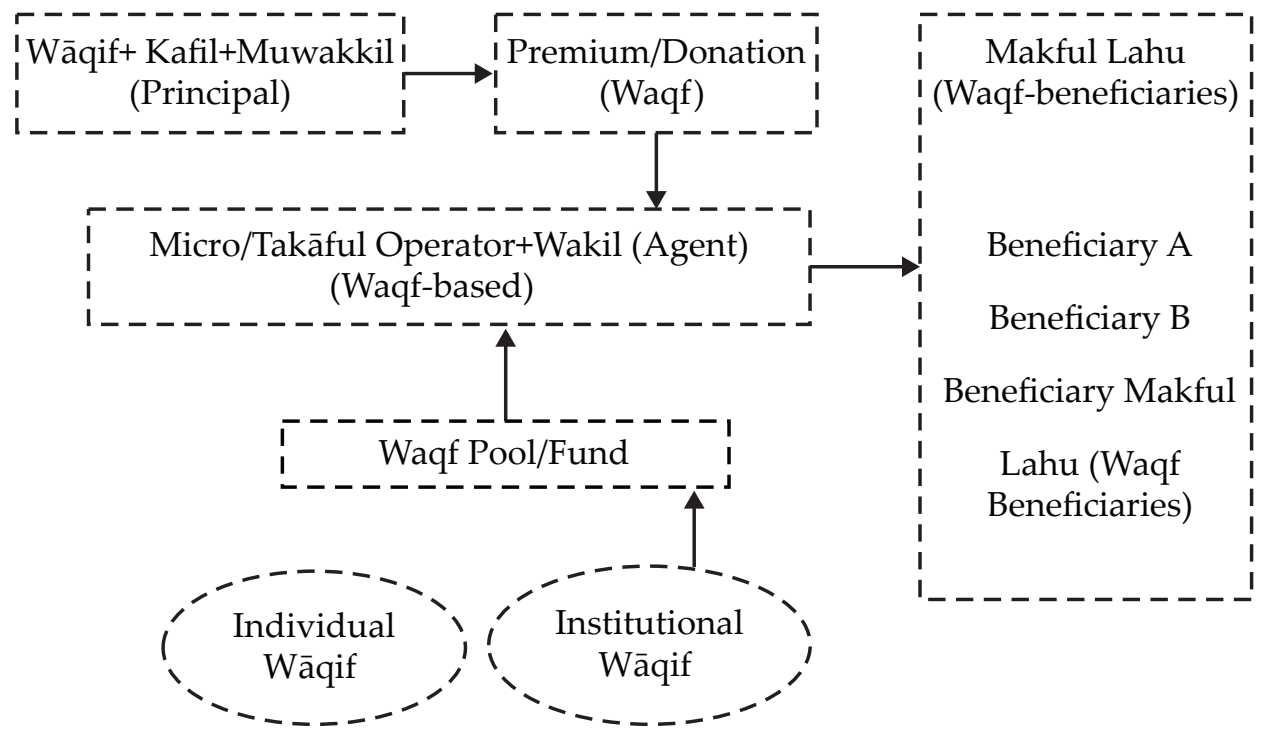

Figure 4.

Waqf-Based Takāful Scheme

As per Figure 4, a wāqif voluntarily takes the responsibility of specific beneficiaries/makfül lahū by acting as his/her kafil. He/she contributes the given sum of money to a waqf pool/fund for the purpose of providing micro-takâful cover to the intended beneficiaries. The takâful operator divides the endowed sum into investment and claim management buckets. Investment returns shall be first directed to maintain the corpus of the waqf capital and the rest is apportioned to the claim management pool. In case a deficit occurs in the pool, an existing or new wāqif (individual or institution) can be invited to further contribute to the pool. Since the invited new wāqif's contribution helps protect and maintain the corpus of an existing wāqif's capital, the new wāqif shall be inspired for expected double reward.

\subsection{Parallel Waqf: A Proposed Model}

In line with the religious spirit of a wāqif's volunteerism, a nominated beneficiary may as well participate in the spiritual benefits of waqf. For this, the concept and practice of parallel waqf $f^{5}$ can be endorsed and promoted. To this end, a financially stable beneficiary of a family waqf (waqf ahli) may seek a parallel waqf model to benefit either a specific or common needy or poor. This model can be practised by resorting to the Mālikī School of jurisprudence. According to the Mālikī School,

5. The term 'parallel waqf' can be defined as a waqf made by a family waqf-beneficiary (mawqufalayh) by passing his/her established beneficial rights in the underlying waqf to a poorer third party for the purpose of securing reward of a wāqif. 
it is permissible to endow the usufruct (manfa' $a h$ ) of a given property as waqf (Zuhayli, 1996; Kahf, 1999). Thus, since the nominated beneficiary of a family waqf is entitled for the beneficial ownership of the related waqf, he/she may exercise his right to transfer the given benefits to others on a temporary or permanent basis.

\subsection{Waqf-Based Social Sukūk: A Proposed Structure}

In addition to waqf-based microfinancing and micro-takäful instruments, the mechanism of waqf could possibly be used for developing waqf-based capital market products as well. A new model of waqf-based sukūk structure can be proposed in this respect to raise funds for social and charitable purposes.

Though there is no existing model of waqf-based $s u k \bar{u} k$, there is good scope for the development of one. A proposed structure of waqf-based $s u k \bar{u} k$ is illustrated in Figure 5 below.

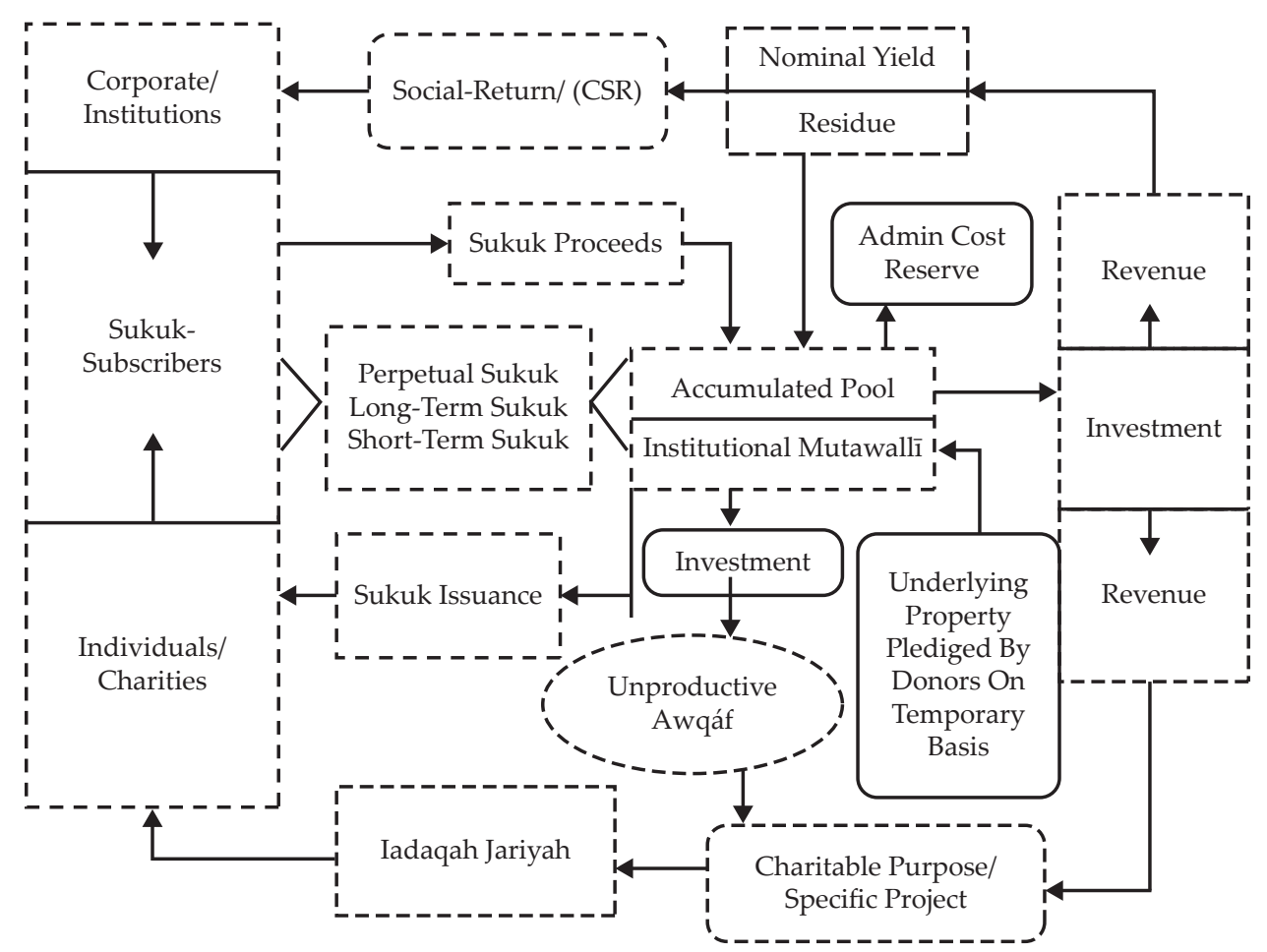

Figure 5.

Proposed Structure of Waqf-Based Sukūk

In this proposed model of waqf-based sukūk, the institutional mutawalliwhich could be a charity organisation or a non-profit institution or a corporate or a governmental body-may issue the waqf-based șukūk for the purpose of social financing. For assurance and credit enhancement, an institutional mutawallie.g., charity organisation, governmental body, corporation or high net worth individual-could pledge specific underlying assets to the special purpose vehicle 
(SPV) on a permanent or temporary basis. The lead issuer issues waqf-based șukūk and the underlying funds are mobilised. The target clients for the sukūk may include individuals, a group of individuals, corporations, non-profit organisations, governmental bodies and charities. The proceeds are invested in the specific projects of $a w q \bar{a} f$ development. In addition, a certain proportion of proceeds are invested in a portfolio of capital market instruments and properties. The accrued revenues from the investment are used to fund charitable and social causes. The objectives of different subscribers may differ according to their public or private profile. For individual subscribers, the motivation for subscription to waqf-șukūk may be purely religious and altruistic. In comparison, for a corporate investor, the stimulus may come from the perspective of corporate social responsibility (CSR). For other institutions and charities, the decision of șukūk subscription may be informed by their interest in social return and also in improving their public profile.

With some fundamental variations aside, the model of this șuku $k$ works similar to the charity-based fundraising model; i.e. investors subscribe to it as a means of charity and social investment. Given the differences in the underlying appetites and capacities of the $s u k \bar{u} k$ subscribers, there may be three variants of the $s u k \bar{u} k$ : long term, short term and perpetual. For those șukūk holders who are religiously motivated, the spirit of the spiritual return would suffice; however, for others, along with the social return, there can be a provision of nominal investment-share yield as incentive. Whereas the short- and long-term șukūk would be redeemable at the maturity date, the perpetual would not. As proposed by Manjoo (2012), the tradability of the waqf certificate/șuku $k$ can be validated by employing the opinion of Abū Hanīfah, who draws an analogy between waqf and 'äriyah. At the end of the maturity date for short- and long-term șukuk, the underlying pledged assets would return to the original owner. The proposed model can be tweaked and adjusted with the consultation of experts to meet regulatory requirements.

Alternatively, the waqf șukūk can be structured on a mudārabah or mushārakah basis as well. Since mudārabah/mushārakah șukūk are structured on the basis of the profit or loss of the underlying business, there is no requirement to transfer ownership of the underlying sukūk assets to the SPV in this model. Thus, the legal and Sharī'ah constraint on exposing the waqf properties to the risk of diminution or transfer of their ownership can be avoided in this structure of waqf șukūk.

\subsection{Waqf Bank: A Proposed Model}

The flexible nature of waqf entails not only innovative financial tools, but it also stretches to cover the functions of a full-fledged Islamic bank. In this regard, a proposal for a waqf-based social bank has been advanced (Mohammad, 2011). The proposed model of waqf-based social bank functions similarly to a full-fledged Islamic bank with the only difference that the profit of such a bank becomes part of the waqf (IRA, 2015). The revenues of the proposed waqf bank, according to Mohammad (2011), would then be deployed to provide microfinancing to the poor and to meet the financial needs of existing awqua $f$.

Compared to this proposal, there is another variant of waqf bank in its nontechnical sense. The model of this waqf bank, which is functional in New Zealand, 
is based on collection and recycling of the unclaimed parts of the qurbān $\bar{\imath}$ animals (slaughtered during the $\overline{\mathrm{I}} \mathrm{d}$ al-Aḍhā festival). The skins are particularly valuable after processing. The products are sold and the resultant proceeds are deposited into a charity pool, which is termed an awqāf bank. Finally, the collected funds are deployed for social and charitable causes (Obaidullah, 2014). ${ }^{6}$

In comparison to these two models of waqf bank, there could be a proposal for another version of waqf bank in its non-technical sense. According to this model, in order to meet the multifarious needs of the potential beneficiaries, region-specific asset/usable commodity-based waqf banks could be established for the purpose of public utility. In other words, the functions of this proposed waqf bank can be similar to the functions of a food or blood bank. The given waqf bank would not collect only cash-waqf donations but also accept a pool of diverse usable, reusable, machineries, technical instrument, chattels and other valuables. The donors of these items would donate these items perpetually. The nature and characters of the acceptable donated items may vary in accordance to the specific needs of rural and urban areas. For instance, in an urban area the range of the donated items may include:

1. Used and unused electronic tools

2. Useful machines

3. Various useful equipment

4. Computers

5. Books, etc.

As far as the rural areas are concerned, the potential list of donated items for waqf bank may include:

1) Cultivators

2) Bicycles

3) Rickshaws

4) Spades

5) Sewing Machines

6) Ropes/String

7) Buckets

8) Seeds, etc.

The institution playing the role of the mutawalli may collect all these donated items along with cash and other forms of waqf. Whereas the investment of the cash waqf would provide continuous returns to meet the administrative and wearand-tear costs, the waqf of tangible assets would benefit the community at large. The donated waqf items may be dispensed by the bank to whosoever needs them (from the locality) based on 'äriyah (usufructuary loan) or qard hasan. The bank may apply a minimum administrative charge on the borrowed items.

To sum up, if applied properly, the proposed mechanism of waqf bank may serve the purpose of a useful repository for various donated items, fulfilling the diverse needs of the community in an easy and cost-effective manner.

6. According to the given data of this New Zealand Waqf (NZ) Bank, the total number of animals required for qurbān $\bar{\imath}$ each year in the western world is almost 5 million. On average, one sheep in New Zealand gives almost 5.6 kilograms of wool. The price of one kilogram of wool is NZ\$2. Thus, 5,000,000 x 5.6 $\times 2$ means that the waqf bank can potentially make NZ\$56,000,000 (Obaidullah, 2014). 


\section{CONCLUSION}

Contemporary awqāf have taken on new relevance with the emergence of the Islamic finance industry. Waqf and Islamic finance have a shared background in terms of being Sharī'ah-based and have similarities in their ethical orientations. Awqā $f$ and Islamic finance can play complimentary roles for each other. The mechanism of waqf promises huge possibilities for Islamic financial engineering and contractual innovation. The device of waqf has already been employed to develop a number of innovative instruments for the Islamic finance industry. The list of waqf-based financial products includes takāful, micro-takâful, microfinancing, wakālah, waqf-based unit trust and qarḍ hasan.

The modern waqf has already evolved to serve a multitude of purposes through its diversified functions and applications. It can be employed as an instrument of finance, a mechanism of legal contract, a vehicle for investment and as a corporate entity. This paper provided an analysis of how the contemporary waqf is in the process of speedy evolution followed by the detailed critical discussion on how the flexibility of waqf mechanism can be deployed to further develop innovative Islamic financial instruments.

Since the last two decades, the pace of evolution in figh al-awqāf (jurisprudence on waqf) has been breathtaking. Due to the consistent momentum of evolution in figh al-awqāf, the modern waqf is ready to embrace the structure of corporate waqf, temporary waqf, cash waqf and waqf of intangible assets such as waqf of intellectual rights.

This paper explored the possibilities of further financial innovation through the effective and diligent employment of the waqf mechanism. The waqf-based products which have been proposed in this paper include waqf-based $s u k \bar{u} k$, parallel waqf, hybrid of waqf-wakālah-plus-kafälah for micro-takāful, and waqf bank. Lastly, as noted, there is still an existing gap in the literature on how awqāf and Islamic finance can achieve greater collaboration both conceptually and practically. Awqā and Islamic finance can mutually contribute to each other's progress, provided better communication and knowledge-sharing occur between the two industries.

\section{REFERENCES}

Accounting and Auditing Organization for Islamic Financial Institutions (AAOIFI) (2015), Shariah Standards, AAOIFI, Manama, Bahrain.

Abdul-Karim, S. (2010), "Contemporary Sharī'ah compliance structuring for the development and management of Waqf assets in Singapore", doctoral thesis, Durham University, Durham.

Abdullah, M. (2015), "Analysing the moral aspect of qard: a Sharī'ah perspective", International Journal of Islamic and Middle Eastern Finance and Management, Vol. 8 No. 2, pp. 171-184.

Abu Zahra, M. (1972), Muhāẹarāt fì al-Waqf. Dār al-Fikr al-'Arabī, Cairo.

Ibn 'Ābidīn, M.A. (2010), Radd al-Muḥtār 'alā al-Durr al-Mukhtār (Vol. 4), Dār alFikr, Beirut.

Ahmad, H. (2007), "Waqf-based micro finance: realizing the social role of Islamic finance", paper presented at the International Seminar on Integrating Awqaf in the Islamic Financial Sector, 6-7 March, Singapore. 
Ahmad, M. (2015), "Cash waqf: Historical evolution, nature and role as an alternative to ribā-based financing for the grass root", Journal of Islamic Finance, Vol. 4 No. 1, pp. 63-74.

Ali, E., Odierno, H. and Ismail, A. (2008), Essential Guide to Takaful (Islamic Insurance), CERT Publications, Kuala Lumpur.

Al-Humoudi, Y. A. (2012), "Islamic insurance Takaful and its application in Saudi Arabia", doctoral thesis, Brunel University.

Al-Khassaf, A. B. (1904), Aḥkām al-Awqqāf, Dìwān 'Umūm al-Awqāf al-Mișriyah, Egypt.

Alpay, S and Haneef, M. A. (Eds.) (2015), Integration of Waqf and Islamic Microfinance for Poverty Reduction: Case Studies of Malaysia, Indonesia and Bangladesh, SESRIC \& IIUM, Kuala Lumpur.

Al-Qardawi, Y. (1985), Figh al-Zakat, trans. by M. Kahf, Dar al-Taqwa Ltd, London. Al-Shaybānī, M. (1997), Sharh Kitāb al-Siyar al-Kabīr, Dār al-Kutub al-'Ilmiyyah, Beirut.

Bakar, M. D. (2009), "Sharī'ah principles governing Takāful models”, in Archer, S., Karim, R. A. A. and Nienhaus, V. (Eds.), Takäful Islamic Insurance: Concepts and Regulatory Issues, John Wiley \& Sons, Singapore, pp. 31-47.

Budiman, M. A. (2011), "The economic significance of waqf: a macro perspective", paper presented at the $8^{\text {th }}$ International Conference on Tawhidi Methodology Applied to Microenterprise Development, 7-8 January, Jakarta.

Çizakça, M. (1998), "Awqaf in history and its implications for modern Islamic economies", Islamic Economic Studies, Vol. 6 No. 1, pp. 43-70.

Çizakça, M. (2000), A History of Philanthropic Foundations: The Islamic World from the Seventh Century to the Present, Bogazici University Press, Istanbul.

Çizakça, M. (2011a), Islamic Capitalism and Finance: Origins, Evolution and the Future, Edward Elgar Publishing Limited, Cheltenham, UK.

Çizakça, M. (2011b), "Waqf in history and its implications for modern Islamic economies", in Kahf, M. and Mahamood, S. M. (Eds.), Essential Readings in Contemporary Waqf Issues, CERT, Kuala Lumpur, pp. 1-42.

Çizakça, M. (2013), "The New Waqf Law prepared by IDB/IRTI and the Kuwait Public Foundation: A Critical Assessment", paper presented at the PNB ParibasINCEIF Centre for Islamic Wealth Management Colloquium, 19 December 2013, Kuala Lumpur, available at: http://www.inceif.org/download/Session\%20 6\%20\%20PROF.\%20DR.\%20MURAT\%20CIZAKCA.pdf (accessed 21 October 2015).

Ellias, M., Kadir, A., Harun, M. (2015), "Cash waqf and its operational issues: an analysis from the Islamic perspective", paper presented at the International Conference on Cash Waqf: Towards the Implementation of Cash Waqf, 28-30 May 2015, Sepang.

Hamad, A. (2015), "The new waqf (Islamic trust) law in the Emirate of Sharjah", Law Update: Latest Legal News E Developments, Al Tamimi \& Co., available at: http://www.tamimi.com/en/magazine/law-update/section-7/june-5/the-newWaqf-islamic-trust-law-in-the-emirate-of-sharjah.html (accessed 20 October 2015).

Hennigan, P. C. (2004), The Birth of a Legal Institution: The Formation of the Waqf in Third Century A.H. Hanafi Legal Discourse, Brill, Leiden. 
IIFA (2013), Fatwa on Cash Waqf, available at: http://www.fiqhacademy.org.sa/ qrarat/15-6.htm (accessed 3 March 2013).

IRTI (2014), Islamic Social Finance Report, Thomson Reuters, Jeddah.

Islamic Relief Academy (IRA) (2015), Comparing the Effectiveness of Waqf and English Charitable Trusts, Islamic Relief Academy, Birmingham, UK.

Islahi, A. A. (2013), "Cash waqf: is it a usurious piety?", working paper no. 43610, Islamic Economics Research Center, King Abdulaziz University, Jeddah, 7 January.

Islamic Development Bank (IDB) (2015), Awqāf Properties Investment Fund (APIF), available at: http://www.isdb.org/irj/portal/ anonymous?NavigationTarget=navurl://097e223be0761cdd343b213dfd855b77 (accessed 22 October 2015).

Joseph, S. (2014), "Waqf in Historical Perspective: Online Fatāwā and Contemporary Discourses by Muslim Scholars", Journal of Muslim Minority Affairs, Vol. 34 No. 4, pp. 425-437.

Kahf, M. (1999), Towards the Revival of Awqaf: A Few Fiqhi Issues to Reconsider, paper presented at the Harvard Forum on Islamic Finance and Economics, 1 October 1999, Harvard University, Cambridge, available at: http://monzer.kahf.com/ (accessed 12 April 2015).

Kahf, M. (2004), Ṣūrah Mustajiddah min al-Waqf, available at: http://monzer.kahf. com/ (accessed 12 May 2016).

Khaleel, F. and Abdullah, M. (2016), “Waqf (Islamic endowment), human capital and humanitarian aid", Interdisciplinary Journal of Economics and Business Law, Vol. 5 No. 2, pp. 36-52.

Mandaville, J. E. (1979), “Usurious piety: the cash waqf controversy in the Ottoman empire", International Journal of Middle East Studies, Vol. 10 No. 2, pp. 289-308.

Manjoo, F. (2012), An Appraisal of Longevity Risk: Conventional and Islamic Perspectives, ISRA Research Paper No. 44/2012, International Shari'ah Research Academy for Islamic Finance (ISRA), Kuala Lumpur.

MIFC (2014), Awqaf: Powerful Socio-Economic Vehicles, Bank Negara Malaysia, Kuala Lumpur.

Mohammad, M. T. S. (2011), "Towards an Islamic social (waqf) bank”, International Journal of Trade, Economics and Finance, Vol. 2 No. 5, pp. 381-386.

Mohsin, M. I. A. (2009), Cash Waqf: A New Financial Product, Prentice Hall, Malaysia.

Mohsin, M. I. A. (2013), "Financing through cash waqf: a revitalization to finance different needs", International Journal of Islamic and Middle Eastern Finance and Management, Vol. 6 No. 4, pp. 304-321.

Mohsin, M. I. A. (2014), Corporate Waqf From Principle to Practice: A New Innovation for Islamic Finance, Pearson Malaysia, Kuala Lumpur.

Obaidullah, M. (2014), Engineering a Waqf for Adahi: New Zealand Awqaf, available at: http://sadaqa.in/2014/04/15/engineering-a-Waqf-for-adahi-Awqaf-newzealand/ (accessed 21 September 2015).

Ramli, A. M. and Jalil, A. (2013), "Banking model of corporate waqf: an analysis of Wakaf Selangor Muamalat", paper presented at the International Accounting and Business Conference (IABC), 22 April 2013, Persada Johor, Johor Bahru.

Shirazi, N. S. (2014), "Integrating zakāt and waqf into the poverty reduction strategy of the IDB member countries", Islamic Economic Studies, Vol. 22 No. 1, pp. 79-108. 
Suhaimi, F. M., Ab Rahman, A. and Marican, S. (2014), "The role of share waqf in the socio-economic development of the Muslim community: The Malaysian experience", Humanomics, Vol. 30 No. 3, pp 227-254.

Tamanni Views (2013), "Corporate waqf: marrying the past with the present", available at: https://marketviews.wordpress.com/2013/01/18/corporate-Waqf/ (accessed 5 October 2015).

Wan, A. and Rahman, W. M. (2011), "The concept of waqf and its application in an Islamic insurance product: the Malaysian experience", Arab Law Quarterly, Vol. 25 No. 2, pp. 203-219.

Wizārat al-Awqāf wa al-Shu'ūn al-Islāmiyyah (1404-1427 H), Al-Mawsū 'ah alFiqhiyyah, Ministry of Awqaf and Islamic Affairs, Kuwait.

Zuhayli, W. (1996), Al-Wașāyā wa al-Waqffì al-Fiqh al-Islāmī, Dār al-Fikr, Damascus. 
This page is intentionally left blank 